\title{
Assessing representations of the imperial cult in New Testament studies
}

\author{
Pieter J J Botha \\ (University of South Africa)
}

ABSTRACT

\section{Assessing representations of the imperial cult in New Testament studies}

A distinct conceptualisation of the imperial cult is common in NT scholarship, in which worship of the emperor is portrayed as a "foreign" development which served primarily political aims, with little integrity and no serious religious significance. This depiction does not do justice to the evidence and is basically ethnocentric. That the imperial cult provides us with a crucial window on the mentality of the Roman Period comes closer to the truth. A few aspects of early Christian literature and history which might be reinterpreted in the light of a more comprehensive understanding of the imperial cult are briefly noted.

\section{INTRODUCTION}

We cannot possibly understand the words and actions of other people if we examine them with our preconceptions; the interpretation of their behaviour and texts must be in the light of their motives, convictions and outlook. The world of the Roman empire, of which the New Testament documents and the earliest Christians are part, was a very different cultural world from ours and in many ways quite difficult to access.

Though the principle of cultural embeddedness is generally acknowledged as important in exegesis and hermeneutics, in practice it is rather challenging to give it its due. Explicitly or implicitly, ethnocentricism keeps on raising its head. I wish to deal with this problem by adopting a stance of pluralism which leads to critical understanding; a pluralist who believes that understanding is real:

"I have tried to argue not from abstractions about the universe but from the facts of our lives as critics, facts which turn out to be values we share with, and derive from, a human critical life that predates and nourishes the life of literature and criticism. Vitality, justice, and understanding, accepted as goods-in-themselves in all human life, lead us into pluralism as critics, just as they led each of us ... out of 
our initial infantile ideocentrism into the recognition of a world built of many centers, irreducible to any one" (Booth 1979:348).

Cultural relativism brings a moral challenge to the task of interpretation because we are dealing with people. Cultural relativism does not obviate or minimise interpretation, but turns interpretation into the arduous and difficult task of finding the "better" explanation. This demands thinking, consideration and application precisely to say something about the "intentions" and values of others. Of course, the very interaction between different motives enables some understanding of shared humanity. It is otherness that provides insight into self.

In this article my aims are:

- to indicate that a fairly typical and standard concept of the imperial cults can be found in NT scholarship;

- to criticise this depiction as inadequate to the evidence and basically ethnocentric;

- $\quad$ to argue that the imperial cults provide us with powerful insights into the "mentality" of the Roman Period;

- $\quad$ to point to some aspects of the New Testament writings and early Christian developments interacting with imperial cult practices which might be reinterpreted in the light of a more comprehensive understanding of the imperial cults.

\section{THE IMPERIAL CULT IN NEW TESTAMENT SCHOLAR- SHIP}

The imperial cult is a well-known part of Greco-Roman religions, and is frequently mentioned in discussions of the "world" or "background" of the New Testament or early Christianity. Among New Testament scholars a sort of consensus has formed which, by and large, depicts the imperial cult as disguised politics, a conglomeration of abhorrent rituals, an expression of personal megalomania by cruel dictators and blatant flattery by opportunistic and unscrupulous subjects. New Testament scholars tend to underplay the significance of the emperors within the actual everyday experience of provincials in the Roman empire, and especially to deny the religious nature and significance of the imperial cults or worship of the 
emperors ${ }^{1}$. In these presentations the imperial cult is shown to be a pretence, which "served primarily political aims", "primarily a sign of political submission" (Lohse 1976:220-221). Instead of being depicted as a living part of the ancient context, it is drawn as a contrast to Christianity; the imperial cult becomes a foil to show the "spiritual nature" of Christianity.

In all fairness, it should be added that precedent was set by some eminent historians of antiquity. "The rulers of Rome claimed the homage due to the gods and masqueraded, for domination over a servile world, in the guise of divinity", according to Ronald Syme (1939:256). Or, according to Bowersock (1973:206), after the "antics" of Commodus and Elagabalus the time had come to make explicit the unspoken assumption: "no thinking man ever believed in the divinity of the living emperor...". Other prominent examples are Nock (1934:481-503); Mellor (1975:2022) and Tripolitis (2002:2).

Since the 1980s, however, a number of investigations into Roman religion in general and more specifically the imperial cults have shown that such approaches are misguided ${ }^{2}$. Even earlier, several scholars showed the centrality of the imperial cult to Roman religion, or warned against underestimating the reality of religious feelings involved with the worship of the emperor (Millar 1973:164, Hopkins 1978, Liebeschuetz 1979:6580). Despite these contributions, the idea that imperial cult equals politics persists among strands of New Testament scholarship. The imperial cult, it is claimed, is of Hellenistic and especially Egyptian background, foreign

1 For examples, among others, see Grant (1962), Cullmann (1957:197-198), Filson (1964:157-158), Koester (1966:188), Blaiklock (1975:301-303), Lohse (1976:220-221), Martin (1978:21-22), Freyne (1980:190-191), Carson, Moo \& Morris (1992:474-475). Reicke (1968:241) is of the opinion that it was Nero who introduced the emperor cult into the city of Rome.

2 Price (1980, 1984b); Phillips (1986); Fears (1981a, 1981b, 1981c); Wardman (1982); Versnel (1988). See especially the more general works of Feeney (1988), Turcan (2000), and the outstanding Beard, North \& Price 1998. Even Fishwick (1978), who is skeptical at best about the integrity and truthfulness of emperor worship, notes rather guardedly the possibility that in fulfilling the rites of the imperial cult "the cult image will have been adored" (1991:527), that "personal zeal or fervour" possibly played a part (1991:531), and that not only banquets, but also other festival rites "contributed to feelings of joy" and "produced a spirit of association and reconciliation among the populace" (1991:584-585). 
to Rome and imported by the emperors. De Villiers (1998:204-205), for instance, describes the imperial cult as of Eastern origins which by means of Alexander the Great and his successors spread around the Mediterranean, to be then introduced into Rome by Julius Caesar. Caesar, according to De Villiers, "connived" to get his cult going in the provinces (1998: 206), and later emperors had to "cultivate" the practice. In the provinces subjects had no problem with practising their own religion and venerating the Roman state deities; but for the state itself, "the emperor cult and the worship of the state gods were not of paramount importance as religious acts; they were, however, exceptionally relevant as political acts through which its subjects attested their loyalty to the Roman imperium and the empire was united" (De Villiers 1998:209) ${ }^{3}$.

\section{A CRITIQUE OF THE CONVENTIONAL PICTURE}

Almost everything is wrong with such a picture. Romans worshipped their heroes as gods long before Caesar. Worship of the living emperor was an integral part of Roman religion. For sure, some had highly skeptical ideas about the gods, but for most Mediterranean people of the Roman Period, worshipping the emperor was a crucial part of living in peace with the divine powers. This is what they believed and really was what they practiced.

A brief review is necessary (I concentrate mostly on Roman evidence; for discussion of imperial cults in the provinces see Price 1984b, Fishwick 1987a, 1987b, 1991 and Botha 1988).

\subsection{Before Caesar}

Long before the principat the Romans believed that gods became humans - or revealed themselves in human form in order to help people in need. The principle underlying the Roman triumphus was exactly this: the conquering general, in his triumph entering the city was experienced by Romans as the making present ("Vergegenwärtigung") of Iuppiter Optimus Maximus. The triumph is the god returning in human form to his temple, standing on a quadriga ${ }^{4}$ and holding his sceptre (the attribute par

3 Again, De Villiers is representative; see, e.g., Achtemeier, Green \& Meye Thompson (2001:40, 566-570); Court \& Court (1990:299); Pregeant (1995:89); Reasoner (1997); Selvidge (1999:15, 266).

4 A four-horse drawn chariot, such as the one used by the Sun, Aurora, Luna etc. 
excellence of the great god), clothed with the ornatus Iovis ${ }^{5}$ with which his statue standing in the Capitoline temple is clothed (Versnel 1970:56-93).

During the Republic the number of gods expanded considerably, and among them we find many Roman heroes. Scipio Africanus, the conqueror of Hannibal, was said to have conversed daily with Iuppiter; when he went to the temple at night time, the dogs did not bark as no dog barks when its master comes home. This Scipio was called the son of Iuppiter, who impregnated Scipio's mother in the form of a snake ${ }^{6}$.

Scipio's fame and the size of his clientela was at its height at the turn of the century ( $\pm 200 \mathrm{BCE}$ ); but astounding stories about him continued to circulate during the rest of the second century BCE. Scipio had a cult, a public cult, and a much longer lived private (family) cult. Within the family (the Gracchi), Cornelia, the second daughter of Scipio Africanus, expected to be invoked as deus parens after her death; her statue was duly set up in public (Pliny Naturalis historia 34.31; Plutarch Tiberus et Caius

5 A purple toga and a tunica stitched with palm-motifs, with a corona, a wreath of gold leaves (taken from the statue of Iuppiter itself), held over the triumphator's head by a slave; see, among other descriptions, Tertullian De corona 13.1; Livy 10.7.11-12. Of course, the triumphator had to lay aside his divine status at the moment of confrontation with the statue of Iuppiter. One's mind boggles at the inconsistencies, obviously the Romans's did not. Between the founding of Rome and the reign of Vespasian 320 triumphs were celebrated, according to Orosius Historia 7.9.8.

6 Today we tend to call these stories "legends" or "myths" (cf. Walbank 1967), but no one would provide money for marble statues, or offer daily libations in honour of a mere myth or legend, so clearly the Romans thought differently. The fact that Polybius (10.2-15) tries to depict Scipio as a cynical, calculating opportunist rather than the conventional image of a man convinced of his own mission and divine assistance, proves how persuasive ancient people found the stories. Similarly, the guardedness of Livy's skepticism shows the popularity of and support for these stories (cf. Livy 26.19: some of these miraculi are true, others not; alia vera, alia adsimulata). Remember that after Scipio's death the sun had a pale light (his death was called the extinguishing of the second Sun); after Caesar's death the sun had a pale light all through the year (Scipio: Diogenes Laertius 4.64; Cicero De natura deorum 2.14, De divinatione 1.97; Caesar: Virgil Georgica 1.466; Plutarch Caesar 69.4; Pliny Naturalis historia 2.98; Julius Obsequens 68; De viris illustribus 78.10). No wonder there was darkness at the death of Jesus, or that for the early church his resurrection was the rise of the new Sun and that He wore a radiate crown (cf. Firmicus Maternus De errore profanarum religionum 24.2-4; Zeno Veronensis Tractatus 2.9.2). Consider also the "woman clothed with the sun" seen by John (Rev 12.1). 
Gracchus 25.4.4) Her two sons, Tiberius and Gaius, received statues everywhere, the place where they died was considered sacred and they were treated like gods (offerings were made, even daily by some people).

Marius Gaius ( $\pm 157-86$ BCE, consul from 107 till 101, and an uncle of Julius Caesar) received libations together with the gods in "every" house after his victory over the Cimbri at Vercellae in $101 \mathrm{BCE}^{7}$.

Marius Gratidianus (twice praetor in the 80s BCE) received statues and libations in all vici of Rome because of his suppression of the debased currency $^{8}$. The cult of Augustus too was connected with the altars of the Lares at the vici in $12 \mathrm{BCE}$.

Caecilius Metellus Pius was worshipped as god with sacrifices in Spain in 74 BCE (after putting down an uprising in Lusitania). He wore the toga picta of the triumphators, supplications were offered as to a god, as well as banquets and games (Sallust Historiae 2.70; Valerius Maximus 9.1.5).

In fact, from $\pm 100 \mathrm{BCE}$ onwards the celebration by cult of individual Roman magistrates became very common. By the late Republic it was considered so natural for a magistrate abroad to have a temple in his honour, that magistrates who took money for this purpose from provincials were exempted from penalties (Lintott 1993:180-181).

But most telling of the divinisation of humans among Romans must be the patronus-cliens discourse: the patronus is frequently described as

7 Whether a "passing honour" as Weinstock (1971:295) claims is beside the point. Romans clearly were comfortable with honouring their heroes as gods; they did this frequently. How to verify a claim such as "no more than a passing honour" is of course impossible; in fact, what would then have been a "proper" honour? On the biased reading of evidence relating to Roman gods and divinities see Clauss (1996).

8 Vicus was the smallest agglomeration of buildings forming a recognised unity, either a village or a ward of a town. Vici could also exist on private or imperial estates. They were administered by magistri or aediles elected by the villagers. Vici in towns had their vicomagistri; those of Rome, reorganised by Augustus, had charge of the street shrines (and sometimes of the fire-brigade). It was the Lares who were worshipped at the vici; so it is quite significant that living benefactors were worshipped here. 
$\operatorname{god}^{9}$. One of the earliest examples is in Plautus, where a patron is called $o$ mi Iuppiter terrestris ${ }^{10}$. The patron earns such divinisation ${ }^{11}$ due to his social prestige and achievements. Cicero is another relevant example with his use of divine epithets for fellow men (e g Lentulus: "parent, god, Salvation of my life, fortune, reputation and name" ${ }^{\text {"12 }}$ ).

What this brief review of some of the more notable instances show is that to say that the imperial cult's introduction into Rome was an "innovation" is clearly an overstatement. Traditional religiosity made the cult possible and continuity with tradition gave the cult power and integrity.

\subsection{Julius Caesar}

The development of the imperial cult was a natural consequence of aspects of traditional Roman religion. With regard to Caesar the point can be

9 The benefactor/benefaction frame of mind refers to a "reciprocity system", a "generic cultural experience" of benefaction and gratitude that permeated ancient Mediterranean cultures (Garnsey \& Saller 1987:148-154, Danker 1982, Charlesworth 1935:8-16, MacMullen 1980:12-14). This mentality is succinctly stated by Pliny the Elder: "To be a god is for a mortal to aid a mortal, and this is the path to everlasting glory" (NHist 2.18). Weinstock (1971:256-259) traces how the fides of the client towards the patron changed into pietas during the first century CE: a form of relationship to someone "to whom one owed one's life or something as valuable as life, the affection and reverance due to one's father".

10 Plautus Persae 99-100. Of course Plautus' texts are comedy, he is poking fun by inverting normal social order; and his depictions of such honouring interaction proves simply relative honour (not absolute, i e, not that Toxilus is Jupiter, but should be treated as Jupiter). The point, however, is the ease and seriousness with which the patron-client relationship slipped into the sphere of divinity.

11 The respons by the cliens: put up a statue and an altar, and sacrifice (a bull or a lamb) to the patronus, for "I am your [goddess] Salvation" (nam ego tibi Salus sum - Plautus Asinaria 712-713); or "mighty Jupiter (etc...)" (nam ego nunc tibi sum summus Iuppiter, idem ego sum Salus, Fortuna, Lux, Laetitia, Gaudium Captivi 863-864). The altar of C Manlius (now in the Vatican Museo Gregoriano profano) graphically reveals a cult dedicated to a patron (Manlius). See Gradel (2002:251-260, esp. 256).

12 In Post reditum Quiritibus ad populum 11: "parens deus Salus nostrae vitae fotunae memoriae nominis". Lentulus Spinther was, as consul, active in Cicero's recall from banishment; cf. Cicero Post reditum in senatu 4.8. Cicero describes his relationship to his supporters as one of pietas (see Epistulae ad familiares 1.1.1, $1.8 .2,1.9 .23,2.6 .2-5)$. 
shown in many ways ${ }^{13}$; I prefer to draw attention to the Julian gentilician cult - that is, the central religious discourse with which the future dictator grew up, and was at home with throughout his life. Like other powerful senatorial families, the Iulii identified their origins with the founding of Rome, specifically with Aeneas ${ }^{14}$. The ancestral god of the Iulii is Vediovis ${ }^{15}$, believed to be identical with Iulus, first of the Gens Iulia. When Aeneas died he became Iuppiter Indiges, Jupiter the "Ancestor", and Ascanius (son of Aeneas, who was also called Iulus) instituted his cult and built him a temple, who himself became deified. So the Iulii accepted Iulus, the son of Iuppiter-Aeneas, under the name of Vediovis, as their ancestral god and offered a cult to him at Bovillae, their ancestral town (and eventually on the Capitol too).

It can therefore be no surprise that Caesar himself was eventually called Iuppiter Iulius (Livy 3.63.7; cf Arnobius 2.73). Caesar saw the honouring of himself as divine as perfectly natural, he expected it and the practice confirmed his convictions. The practice was dynamic and organically interwoven with "normal" religious developments.

Gaivo Fouvio Kaisar ol dia; ta; praxei prosagoreuqei; qeov (Diodorus 1.4.7) ${ }^{16}$. He was indeed addressed as god, with the senate awarding him, while he was still alive, temples, altars, divine images, a golden throne (cf Suet. Caes. 76). There were special priests dedicated

13 There are a number of outstanding discussions of divus Iulius: Weinstock (1971); Gordon (1990); Fishwick (1992); Gradel (2002:54-72); Meier (1990).

14 The Trojan hero associated with the foundation of Rome. Disconnected anecdotes about his wanderings probably circulated during earlier times depicting a hero with no definite characteristics except a scrupulous piety. Virgil's portrait of Aeneas is based on the piety ascribed to him by Homer, but this is amplified by Virgil to the Roman sense of pietas: a devotion to his father, to his mother and the gods in general, and to the great destiny of Rome.

15 "Young” Iovis/Jupiter? Cf Rose (1970), Weinstock (1971:8-12).

16 “... because of his achievements Gaius Julius Caeasar was hailed god". Diodorus is presenting a brief preliminary outline of his Biblioqhvkh (completed during the $30 \mathrm{~s} \mathrm{BCE}$ ) and mentions that the Roman commander, Caesar, who was deified, subdued the Celtic tribes. In 5.21.1 Diodorus narrates that no hero or leader made any campaigns against Britain; Caesar, "who has been called a god because of his deeds", being the first to have conquered the island (G a vo K a i 5 a r ol dia; ta; praxei ejonomasqei; qeo; ktl.). Surely one must find this association of military conquests with deeds worthy of deification as disturbing. 
exclusively to the service of Jupiter, Mars, Quirinus and Julius Caesar (Weinstock 1971:305-308).

So, whether the reference is to the honouring of Caesar as god in 49 in the Roman municipa, after crossing the Rubicon ${ }^{17}$, or in the East after his victory at Zela, or when his statue was erected on the Capitol: all these activities should be acknowledged as genuine Roman religious experiences.

Ovid (Fasti 3.703) claims that it was Caesaris umbra (his shadow) that fell to the dagger in $44 \mathrm{BCE}$, implying that the divus ${ }^{18}$ did not die, but was translated to immortality. Our contemporary ideas concerning "divinity" and "divine honours" clearly do not fully recognise the reality of the Roman perspective. The whole modern conception of divinity as an ineffable and superior "godhead" relates most artificially to Roman convictions (Price 1980:29; Mellor 1992:387).

\subsection{The reforms of Augustus}

Conventionally, Augustus has been understood as a traditional leader, hesitant to participate in or encourage emperor worship. This depiction is derived from comments by Suetonius (Augustus 52) and Cassius Dio. Suetonius is actually describing the "considerate behaviour" of the emperor (cf Aug 51); part of his kindness being the rejection of divine honours. Cassius Dio (51.20.6-8) claims that in Rome itself and in Italy generally, no emperor, no matter how greatly venerated, has ventured to instruct that divine rulers be honoured. Casssius adds that, even so, divine honours are conferred after their death upon virtuous emperors.

17 Cicero Epistulae ad Atticum 8.16.1; for the reading vero deum see discussion in Weinstock (1971:300 n 6).

18 The supposed distinction between divus and deus is with regard to the conventions of antiquity misplaced (see Pötscher 1978:388, Clauss 1996:410-411), although divus for Caesar had its uses due to the archaic associations of the term (Wardle 2002). The "verschleiernde Sprachakrobatik" which one finds in many discussions about the divinity of Roman emperors would be a most interesting study in its own right. There is no need to be apologetic about the distinctiveness of Roman beliefs. Harland (1996) draws attention to the important place of the emperors within interconnected social, political and religious realms of life in the empire, which has not been sufficiently acknowledged, due to restrictive and modernising presuppositions and assessments. 
Clearly Cassius' sweeping claims are simply wrong; we possess epigraphical evidence spanning several centuries that prove that emperors were worshipped in Italy, including living ones ${ }^{19}$. More accurate is the impression left by Tacitus (cf. Annales 1.10.6): “... when Augustus chose to be himself worshipped with temples, statues, flamens and priests like those of the gods ...".

There was a very skillful art related to accepting (and declining) divine honours ${ }^{20}$. When Augustus refuses divine honours from the Senate, his association with the gods is already long established, and his statues are already standing in various temples. Full divine honours was a standard notion proposed for all the Julio-Claudian emperors. It was constantly rejected from Augustus onwards, not because of any modesty on the part of any emperor - no emperor could possibly forget the ominous link between acceptance of state divinity and death as revealed by Julius Caesar's murder - but (almost shamelessly) to show off moderatio.

But is the point not that the offer was made, again and again, rather than that the emperor did not accept the offer? Divine honours simply formed the way to define the imperial position. This is the most reasonable explanation; this is how subjects thought about their princeps, what they believed about him and what they expected of him, and also what the emperor thought about himself, believed about his role and strived to achieve in practice.

Once again, an astounding wide range of evidence can be marshalled to show that Octavian (and his fellow Romans) did believe him to have

19 Inscriptions from all over Italy witness to the temples, priests and priesthoods, and sacrifices to the living emperor; the evidence is most abundant from Augustus' reign. See Hänlein-Schäfer (1985:17-25), and the literature referred to in note 21 .

20 Statements about refusal of divine honours is first and foremost about a legal point: such an emperor does not receive a state temple; worship of the emperor public or private - is not the issue. Octavian ostensibly avoided direct deification, but most definitely not with regard to all other levels. Also, changes in political situations and ideology over a period of time should be taken into account. Before 31 BCE Octavian projected officially an image that would not give open offense to old republican sensibilities; this changed after $27 \mathrm{CE}$. By contrast, Octavian/ Augustus is commonly depicted as godlike in private works of art throughout his lifetime (Pollini 1990). 
been a $\operatorname{god}^{21}$. To think about oneself (oneself being an aristocrat, and leader of powerful armies) having divine associations and to portray oneself as such; for others to think about the powerful in such terms, were notions that came naturally to these people. Association with the gods was part and parcel of Augustus' psychological and mental makeup, not something artificially adopted or imported at a late stage in his life.

To understand Augustus' shaping of the imperial cult and the success thereof, we need to contextualise his religious activities and reforms ${ }^{22}$. Pax, in the words of Tacitus (Annales 1), required a princeps after a century of civil discord marking the failure of Republican, constitutional government. To appreciate the Romans's understanding of that crisis and the Augustan resolution, we must percieve that the breakdown of peace which the Republican constitution could not prevent was mirrored in the breakdown of a Republican religion which could not maintain the pax deorum. The consuls under the Republican government had religious as well as political responsibilities. The cultic religious acts of republican magistrates were found to have been as ineffective as their administrative and governing ones. The pax deorum, like the civil peace, had lasted under the republic only for a time and on an ad hoc basis. Lucan (Pharsalia 1.522-605), writing shortly before $65 \mathrm{CE}$, describes the natural turmoil of the civil war but also emphasises its supernatural counterpart. The chaos of

21 Extensive discussions in Liebeschuetz (1979:55-100), Clauss (1996:411421); Gradle (2002:110-139); Zanker (1990:42-64, 232-239, 294-328); WallaceHadrill (1993:79-97). Cf. also Fishwick (1991:436-445), who prefers to read the evidence showing honour for the emperor, who is above men but below the gods. $\mathrm{He}$ is rightly criticised by Clauss (1996). What convinces me that Fishwick is forcing the evidence is the very ambiguity he emphasises; both emperor and subjects exploited that ambiguity, and precisely because they were serious about next to his "menscliche Wesenheit" there was in the same person also his "göttliche Wesenheit" (see Fischwick 1991:439). And, let us acknowledge the simple fact that the ambiguity can only exist when it is possible for a human to be a god.

22 "... these imperial rituals can more helpfully be seen as part of the general 'restructuring' of religion at the time - drawing on the longstanding traditions of Rome, though increasingly focussing on the person of the emperor himself. ... even the apotheosis of the dead emperor was as much rooted in 'tradition' as it was a radical innovation of autocratic rule — and inevitably problematic for that reason" (Beard, et al 1998:169). The significance of religious change in the Augustan period "are within the system, not subversive of it" (North 1986:253). 
society was mirrored in a chaos in nature marked by wide ranging omens, which, to use a phrase from Lucan, nature "at variance with herself, had brought forth" (discors protulerat natura, 1.589-590) ${ }^{23}$.

Civil disorder, defeat against external foes, imminent economic collapse and such disasters were seen as reflections of cosmic disorder. Throughout his history of Rome, Livy repeatedly lists in lurid detail portents and prodigies calling for expiation by the Roman magistrates through their presidency over the rites of augury ${ }^{24}$. The Republican practice of augury and the taking of auspicia by elected magistrates was part and parcel of the political and constitutional requirements which magistrates performed daily ${ }^{25}$. In augury, one read the future to gather crucial information for political, economical and ethical decisions, on the lining of an animal's stomach or in the flight of birds. The cultic acts performed to secure such objectives were justified in terms of the interrelatedness of the natural and social order with the divine.

It is against the background of cultic failure that we should understand the reorganisation of the state religion around the figure of Augustus; the reformed "republic" of Augustus has as its counterpart a reformed religion focussing on Augustus not only as pontifex maximus but also as divi filius. In his Res Gestae (13-15) Augustus boasts of the closing of the Gateway of Janus Quirinus three times under his principate ${ }^{26}$. Dio has a

23 Lucan's poem is more correctly titled "Concerning the Civil War", and describes the contest between Caesar and the Senate.

24 Livy 1.20.7, 4.21.5, 5.14.4, 5.15.1, 24.10.13, 27.37.6-8, 41.16.6, among many instances. See also Julius Obsequens, passim.

25 See, e g, Cicero's De natura deorum 2.2-4; De divinatione 2.74. On augury/divination in Roman society and religion: (Aune 1993:791); Barton (1994, 1995); North (1990, 1986); Van Rossum (1994).

26 The Res gestae divi Augusti is one of the four documents Augustus deposited with the Vestal Virgins towards the close of his life (the other being his testament, directions for his funeral and a report on the military and financial state of the empire). The tablets on which the Res Gestae were engraved have not been found, but the greater part of the document has been recoverd from a Greek-Latin inscription in the temple of Rome and Augustus at Ancyra, and texts found at Apollonia and Antioch (both towns in Pisidia). The text is available in Ehrenberg \& Jones (1955:2-31). The closing of the arched gate near the Palatine dedicated to Janus Quirinus reflects the conviction of "universal" peace. Augustus' closures visibly symbolised his pacifying the Roman world: "he seduced everyone by the delights of peace" (cunctos dulcedine otii pellexit, Tac. Ann. 1.2). 
very significant comment on the significance of this event: during the first triumvirate in $63 \mathrm{BCE}$ the augurium salutis could not be obtained due to too many unlucky omens. Only when the senate closed the gates of the temple of Janus under Augustus as augur was the ritual successful (Dio $37.25 ; 51.4)$. The achievement of peace by Augustus is a religious act of sucessful augury that could not be performed under the Republic. Note that Suetonius (Augustus 7) claims that in augurium lies the significance of Augustus' name ${ }^{27}$.

On 30 January 9 BCE a monument was dedicated by the Senate to commemorate Augustus' safe return from Gaul and Spain. This was not an altar devoted simply to Pax but to Pax Augusta ${ }^{28}$. The iconography of the altar's relief shows "the epiphany of Pax, Felicitas, Concordia and Pietas in the person of Augustus and his restoration of the Roman and universal order" (Fears 1981b:885). Towards the end of the republic an extraordinary pax deorum was required by the extraordinary convulsion of nature as well as by the convulsion of society in the civil war. Augustus achieved this extra-ordinary pax through his association with these divine entities, derived from the cult of virtues and held to reside exclusively in himself alone. In such a matrix we find the changes in the originally Republican cult of virtues where, as a result of the restoration of both the social and natural order, the virtues of Victoria, Pax, Concordia, Salus, Fortuna, and others ceased to be abstractions and developed a concrete divine shape ${ }^{29}$. Adjectival qualifications such as Juno Sospita or Janus Quirinus are now applied to designate the emperor's person as the sphere, functional or temporal, in which the deity has manifested his or her characteristic power (cf Fears 1981b:886). From Tiberius onwards we find examples of the continued qualification of each individual deity in the cult of virtues so as to appropriate them to the godhead of the imperial cult. In other words,

27 Actually, the title/name "Augustus", granted Octavian in $27 \mathrm{BCE}$, is an archaic word. Suetonius (Aug. 7.2) suggests a reference to the Roman belief that Rome was founded by "august augury (augusto augurio). The straight forward association of the word is simply "divine", as most commoners probably took the name. Ovid (Fasti 1.607-611) sees it as synomous with sanctus or divinus.

28 Cf Res Gestae 12; Ovid Fasti 1.709-722; Vergil Aeneid 2.293-295, 8.81-85, 193-305. Excellent descriptions of the Ara Pacis are available in Claridge (1998:184-189), Wallace-Hadrill (1993:70-75), Simon (1986:28-46).

29 Victoria: Livy 35.9.6; Concordia: Livy 9.46.6, 24,22,1; 24,22,13; 26,23,4; Fortuna: Livy 2.40.12; 23. 19.18; 43.13.4 ; Salus: Livy 9.43.25. See Fears (1981b). 
these virtues had ceased to be separate divine forces, but had become, as it were, persons within the corporate godhead of the divine emperor.

Augustus' transformation of society was accompanied by a transformation of nature into a saeculum aureum. Virgil's fourth Eclogue (40 $\mathrm{BCE}$ ), written in the form of a prophecy (by the Sibyl of Cumae, under the inspiration of Apollo) expects the return of the Golden Age; the agent of this return is a newly born wonder child whose birth would be accompanied by a miraculous transformation of nature. He will free us from the last traces of sin and pacify and rule the world (Eclog. 4.4-25). By the time that Virgil had written Georgics (29 BCE), the puer had become identified with Octavian himself, whose birth was responsible for the pax deorum shown in the natural order in which earth yielded its bounty (1.24-42), and who, like the puer of Eclogue 4.17, would rule the globe (reget patriis virtutibus orbem). When accepted by the gods into their number, Octavian would prove to be both the "increaser of the crops (auctorem frugum)" and "the master of the seasons (tempestatumque potentem)" (Georgics 1.27). He would be welcomed as such by the "great world (maximus orbis)" (1.26). No wonder Tacitus (Ann. 1.73) recounts that worshippers of Augustus were to be found in all Roman households (cultores Augusti qui per omnis domos ...).

The "golden age" with its manifestations of Fortuna, Providentia, Salus, Concordia, Pax and Victoria flows from the divinity of the emperor (and in Aeneid 6.791-94 Virgil finally identified Augustus as the bringer of the saeculum aureum). This aspect of imperial worship reveals that the Augustan (and later) rituals produce these qualities, not as transient states to be lost again as under Republican magistrates, but everlastingly. They produced not just fortuna, providentia, salus and such for the following year, but for a golden age, a saeculum aureum that was in a process of birth.

Augustus was to celebrate these themes in connection with his own person in the iconography of his monuments, and many examples have survived (Simon 1986). In one such example, a cameo (the famous Gemma Augustea), the divine foreordination of Augustus' rule is linked to Jupiter. Capricorn appears above the head of Augustus, who is himself represented as the earthly counterpart of Jupiter, semi-nude (Fears 1981a: 57-58, Fears 1981c:810-812). Incidentally, Capricorn (Augustus' natal sign) plays a significant role on the Augustan coinage of 22-12 BCE. On 
the day of Octavian's birth, the astrologer Publius Nigidius Figuluus is said to have proclaimed the birth of the ruler of the world, and "that the gods of Egypt had placed Capricorn in the sky to commemorate the liberation of the world from the tyranny of Typhon and the re-establishment of divine order" (Fears 1981a:58) ${ }^{30}$.

What becomes clear is that the imperial cult had acquired a sacramental character through which its ritual maintained the extraordinary pax deorum. The reorganisation of the cultus over which Augustus and his successors were to hold power as pontifex maximus and as divi filius made the imperial ruler the mediator of metaphysical order and thereby peace.

The well-known traditional notions of peace, salvation, concord and others were given a concrete focus in Augustus and the saeculum aureum that he inaugurated, as had the old republican cult of virtues (cf. Fears 1981b:834-835). Therefore, Shotter (1991:47) is quite correct when he notes that the imperial cult became "the ultimate expression of pietas, and thus of Augustus' guidance of Rome back to its old and hallowed standards". It is these merits, personalised as they were in the collective personality of the emperor, that are celebrated in various inscriptions.

One is a decree of the Council of the province of Asia (9 BCE). Bear in mind that the author is a Roman proconsul and member of the old Roman aristocracy:

...Providence (promoia) granted to us Augustus ... blessing us and those after us with a saviour (w\$per hmeih kai; t oi' meq/Ehma L swthra carisamemh) ... and whereas Caesar on his appearance surpassed all hopes and anticipated good tidings (0) Kais ar t $a i r$ e) pida twh prolabout wn euangevia pant wn upereghken) ... not even leaving those [benefactors] to come any hope of surpassing him; and whereas the birthday of the god was the beginning for the world of the good tidings through his coming (diV a uf on

30 Tuf wn, Typhoeus, traditionally the giant who tried to force Jupiter from heaven, hence a chthonic dragon or monster representing the counterpart of the great gods. 
eujngeliwn) ... a crown be awarded to the person proposing the greatest honours for the god ....

The bottom line of all this is the importance of not secularising or demythologising the concept of pax achieved by the Roman rulers. The princeps was not justified in terms of the utility of a single ruler harmonising a state machine from which divine life was absent. Quite the contrary.

\subsection{The rest of the Julio-Claudians and the Flavians}

Within days of Augustus' death the Senate honoured divus Augustus with his own temple with a flamen. Tiberius, as Augustus before him, called himself divi filius.

Veneration as divus during their lifetime can be observed for Tiberius, Gaius (who changed the traditional formulation Iuppiter Optimus Maximus to Optimus Maximus Caesar), Claudius and Nero. All these principes were dei praesentes and their cults were practised by a population acknowledging their immense power ${ }^{32}$.

With regard to the provinces, a distinction is usually drawn between whether or not the cult was directed toward the reigning emperor or the deceased Augustus (and his deified house), and accordingly two lines of development in the provinces during this period are described: one with an emphasis on immediate loyalty toward the current ruler, encouraged on the frontier and in potentially disruptive areas, and the other in more Romanised and sedate areas (cf Fishwick 1987a:165-167). The archaeological evidence, however, clearly shows that such distinctions cannot be maintained (Fishwick 1996; Futrell 1997:88). The deceased Augustus and the current living emperor were worshipped throughout the empire, including Rome and close vicinities. It is also noteworthy that we find a marked

31 Supplementum Epigraphicum Graecum 4.490, lines 30-50. The almost completely reconstructed text of the decree is available in Ehrenberg \& Jones \#98 (1955:81-83).

32 See Gradel (2002:140-161); Clauss (1996:421-426); Barrett (1989:140-153); Reynolds (1996); Hoskins-Walbank (1996). With regard to the "excesses" of Gaius: "The stereotyping of Caligula the monstrum does not depend on his craving for divine honours" (Gradel 2002:146). "Whatever the precise form of the worship of Caligula ... it is clear that he did not impose it on the Romans" (Barrett 1989:152-153). 
increase of the title "lord" (kurio , dominus) for the emperor from the time of Nero and later (Frenschkowski 2002:98-102).

The members of the Flavian dynasty supported the development of various imperial cults quite fervently. Their interaction with the various forms of emperor worship sparked innovation in terms of cult and signalled another major period of development of provincial worship, analogous to that of Augustus (cf Fishwick 1987b:295-300).

The Flavian version of the cult emphasised the construction of temples, serviced by a flamen divorum, and these divi clearly included not only the deceased deified emperors (this would limit the object of worship solely to the Julio-Claudian dynasty, which would do the new ruling family little good). Not only was the imperial cult standardised as worship of the living emperor but it was also extended to areas relatively neglected by the Julio-Claudians, notably the Iberian peninsula and North Africa.

\subsection{Result: the emperor as god}

Even this extremely brief review must forcefully remind us of the reality and the influence of the emperor as a living god. "Der princeps war Gott. Er war dies von Anfang an, seit Caesar und Augustus, er war es zu Lebzeiten, er war es nicht nur im Osten, sondern auch im Westen des römischen Reiches, in Italien, in Rom" (Clauss 1996:400):

"... even if worship of the emperor might upon occasion have amounted to nothing more than adulation or political calculation, or even if it was sometimes mere hypocrisy, there can be no doubt about the existence of a widespread conviction that the ruler was a god, or was at least something like a god. His insuperable and therefore divine power, at once a very real and present force for most of his subjects, was regarded by these people as the guarantee of their salus. Moreover, to secure the continual operation of this power, it was necessary to fulfill the demands of cult — with prayers, victims, and further rites - in the same way as one might acquire the help of other gods. The only difference was that the emperor was also a human being, liable to illness and death, i.e., he could guarantee the salus of his subjects only when his own salus was secured. Precisely this double nature of the ruler, however, magnified the importance of his cult. On the one hand, it was necessary to honor and adore him; but it was also essential to 
sacrifice for his safety. In other words, one sacrificed not only to him as a god, but also for him as a man" (Alföldy 1996:255).

\section{TOWARDS AN UNDERSTANDING OF IMPERIAL CULTS}

\subsection{Dealing with bias}

Weinstock (1971:vii), in his comprehensive study of the divinisation of Julius Caesar, warns that in his depiction some of Caesar's features may seem unfamiliar. This is due partly to new evidence, but partly also because of his "reluctance to share the view that Caesar was rationalist or that he and Roman religion can be judged in the light of puritan ideals". Such a view he believes "to be modern prejudice" (Weinstock 1971:vii).

An extremely important hermeneutical principle is indicated by these remarks ${ }^{33}$, but this immediately raises a further question: with what then to judge - as we must, otherwise there cannot be understanding. The point of scholarship is to advance understanding beyond projection and prejudicial distortion. The practice is not simple nor easy, and analysis of one's assumptions and values are the useful way forward. The way to do this is to strive to see things as they themselves saw things, to attempt some "thick description" that would be recognisable to them.

Consequently, one should prefer to follow the approach of anthropology in this regard: not suppressing one's intellectual tools, but using it to point out those aspects which cannot be incorporated into our own cosmology. In such a way the quest for understanding that which is not merely one's own fabrication is launched: a quest or hope to be able to assess the radical otherness of the texts. The proposition is that we impose upon ourselves a temporary self-alienation, endeavouring to consider the data as an expression of a foreign culture, in the hope of avoiding the danger of adjusting their expressions to our preconceptions (see the very useful exposition of these issues in Oudemans \& Lardinois 1987:1-47).

33 Similar indications by Clauss (2001:9): “...we must unthink a great deal if we are to understand conditions in the ancient world". And Barrett (1989:140): "Most importantly ... we must be careful not to impose on the ancient world our own preconceptions of what constitutes a sound and healthy relationship between the human and the divine". 


\subsection{Roman cosmology}

Herz (1988:138), who is quite representative, writes: "Zwischen dem Kaiser und einem Gott existierte eine unüberwindliche Schranke". Given the evidence we have this is an astounding claim. In fact, the very opposite is true. Toynbee provides a more appropriate starting point: "Men and gods were not on two completely separate and differentiated levels, the one on the natural, the other on the supernatural, plane. They occupied either end, as it were, of a single sliding scale" (Toynbee 1947:126-127).

In this sense Craffert has done well with his description of the worldview of the time as "a densely populated cosmos", meaning that both humans and non-human beings (gods, demons etc.) occupied the same spaceworld: the gods could be far off, but they and humans existed in the same "natural" world (Craffert 1999:24-27). Broadly speaking, in ancient perspectives gods were immortal humans and humans mortal divinities: the borders between both could (and were often and easily) crossed (cf Clauss 2001:9-13).

Oudemans and Lardinois (1987:31-47) point out that modern day people, usually with a Western cultural background (but not necessarily, I would add) live in a "separative cosmology". The universe is ordered in eternal laws and there are no intrinsic limits to a person's ability to obtain rational knowledge of nature. Nature itself has no divine aspects, it is just matter and therefore there are no moral limits to the conquest of nature. In contrast, "interconnected cosmologies" do not know such a rational separation of nature from the divine. Rather, nature is permeated with religious aspects. This does not preclude intervention by humans in natural processes, but such technical knowledge deals only with one aspect of nature's divine power, which is essentially far too powerful to be mastered by any human. In interconnected cosmologies,

"[d]iversity is not reduced, but woven into a texture of implicit connections, at the expense of clearness and distinctness. No unambiguous unity is attained, but a pictorial whole of interconnected nodes. This does not imply that interconnected cosmologies are confused ... [just that] the categories distinguished remain interlinked by networks of metaphorical and metonymical lines" (Oudemans, et al 1987:49).

The Roman world (and obviously, that of the early Christians) is an instance of an interconnected cosmology. And to point to just one connota- 
tion, the elaborate role of statues in the world of antiquity makes sense. These statues were not just representing or depicting someone, but were possible sources of power, sometimes revelation (cf Gordon 1979).

Whereas we, nowadays, are inclined to translate images into abstract ideas, abstract ideas were to them manifest in images. In the first-century Mediterranean world, images, or rather the ways in which people perceived images, were based upon a quite different psychology; they were apprehended directly, much as a dream operates with images. Consequently, simulation flowed over (or shifted) into the veridical. Suggestion became reality.

What needs to be visualised is a sort of limitless access to all godhead, where public and private life, every aspect, even the tiniest everyday details, was modulated by countless religious rituals and observances.

\subsection{Real religious content}

To my mind the recognition that the imperial cult expressed genuine religious content must be the starting point of a serious discussion - a point stressed by several studies (Pleket 1965; Bickerman 1973; Hopkins 1978; Price 1980, 1984a; Harland 1996; Phillips 1986:2752-2757). The "cult of the ruler was a central element of ancient religious life" (Alföldy 1996:255).

The imperial cult was designed to express eusébeia (contra Bowersock 1973:182-184). Many inscriptions witness to the fact that acts of imperial devotion were seen as a display of piety (Price 1984a:88-89). The emperor was present in the household, from statues of Augustus in private gardens (Tacitus Ann. 1.73) to bronze statuettes of Augustus among the lares of the house (cf Suetonius Vit 2.5), the emperor was obviously worshipped privately. Sometimes (with popular emperors?) "likenesses" of the emperor were "anywhere and everywhere" (cf Fronto Epistulae 4.12.6). But the emperor was also in the compitales, the street shrines of the vici. He received prayers, libations and, in his temples, sacrifices.

We should not underestimate the emperor as focus of source of help and assistance. A tremendous earthquake in $17 \mathrm{CE}$ (Tacitus Ann. 2.47) had a profound influence on Sardis's history, and on more than its physical foundations. "Survivors of the disaster saw the temple of Artemis and Zeus, and probably that of Meter, overthrown and lying in ruins for half a 
century, the gods unable to protect them. Not unnaturally, from gods that had failed them, they turned to the praesens divus, the 'present god', the emperor who was the first to help them in their dire plight" (Hanfmann 1983:135). The ideology and the practice of the Empire was that the emperor was, as a "king", accessible to his subjects in a way which now seems incredible; in a very real sense saviour and final help (cf Millar 1977:11; Gradel 2002:50-51).

\subsection{A window onto the Roman worldview}

Obviously, the imperial cults are not everything Roman religion was about, and definitely not the single controlling element of non-Christian worship. The plural should be noted, as an immensely wide variety of activities is included under the umbrella term "imperial cult".

Allowing for these qualifications, it is still quite clear that from the time of Augustus to that of Constantine, the cult of the emperor was, on all accounts, the most important type of worship. It is worthwhile citing Alföldy (1996:255) on this point:

"...this cult was in a certain sense the most important cult of the Roman Empire before the triumph of Christianity. The other divinities of the Greek and Roman pantheon were exchangeable at the pleasure of the individual. Local cults in the provinces were normally limited to only one town, one clan, or even one sanctuary; and the mystery cults attracted only small and particular groups of the population. In the cult of their emperor, however, practically everybody was involved".

Consequently, the real significance of the imperial cults lies in the realisation of how these beliefs and practices bring together essential aspects of not only what is Roman, but of the worldview and cosmology of the first century and late antiquity. It opens, so to speak, a window onto the Mediterranean mentality of the Roman period. Like few other social institutions, the effort to understand the imperial cult enables us to recognise a world that is not ours.

\section{RETHINKING THE INTERACTION BETWEEN EARLY CHRISTIANITY AND IMPERIAL CULTS}

Paradoxically, the cult reminds us, on the one hand, that even early Christianity must have been a very different religion from its modern descendant, "much less familiar in its doctrines, morality or organisation 
than we might prefer to imagine" (Beard, et al 1998:x), but also, on the other hand, that the history of Roman religion "is nothing less than the story of the origin and development of those attitudes and assumptions that still underlie most forms of contemporary religious life in the West and most contemporary religions".

There are indications that both the complexities and the importance of the imperial cult are being taken seriously by some New Testament scholars. In the following paragraphs a few lines for possible further investigation are briefly described.

\subsection{Messianism and politics}

The most obvious association would be Christological development in the early church. This is of course an immensely complicated issue, which demands extensive and wide-ranging discussion. I note two aspects.

It must be clear that the longstanding interpretation of Christological titles and devotion to Jesus as non-political or even a-political is not only terribly naive, but simply wrong. Although the use of kurio for emperors goes back to Augustus, we have from the reign of Nero and onwards a remarkable increase of kurios-piety: kurios becomes an important part of piety expressing a personal relationship to the far-away saviour, ruler, supreme judge and guardian of public prosperity. That in the same period the major Jesus-literature gets written, with similar use of titulature, must be highly significant. Undoubtedly the followers of Jesus were attempting to evoke connections and contrasts, and the very essence of those contrasts would be a way of living, a life-style - otherwise there would not have been any point to calling Jesus "kurie, kurie" (Lk 6.46). To suggest that the Man from Nazareth is also more than the lords of political independence and of imperial piety and propaganda is to make a statement with profound socio-economic consequences and implications for relationships involving authority or power. There is a growing awareness of these aspects in New Testament scholarship ${ }^{34}$. Unfortunately, much of the current investigations still reduces the interaction with the cult to one of opposition. The undeniable his-

34 See Horsley (1997, 2000); Cassidy (2001); DeMaris (2002); Frenschkowski (2002); Lietaert Peerbolte (2002) for recent examples. 
torical fact that by the fourth century the church found expression for its life in adopting forms of the imperial cult is indication enough that simple opposition was not all that was going on (cf MacMullen 1969:185-204, 236).

The divinity of Jesus. Was the ascription of divinity to Jesus by his followers - which, based on the evidence (including significant New Testament traditions), cannot be doubted - absolute, or relative? That is, is the real question we should ask not whether someone, emperor, beloved, Jupiter or the Man of Nazareth is a god, but to whom this was so? Jupiter did not receive his incessant, sumptuous sacrifices because he was a god (among innumerable others), but because he was the foremost, most powerful god of Rome. One can worship Christ in an infinite number of ways, but one's practices and rituals are all ways of constructing a reality expressing convictions about Him. Did the focus on His nature not possibly become a smoke screen obscuring questions of relationship and lifestyle?

\subsection{Contextualising specific New Testament writings}

\subsubsection{Luke-Acts:}

In contrast to the Book of Revelation - the message of which most scholars accept should be related to the practices of emperor worship (and consequently Revelation is frequently analysed by means of reference to aspects of the cult) — the synoptic Gospels are usually seen as quite unrelated to imperial cult issues.

However, two very clear indications must be heeded by investigators into Luke-Acts. Firstly, the general thrust of Luke-Acts has long been recognised as being aimed at a high-minded audience of the Flavian period, and in Acts we have the one NT book expressly relating to a Romanised context. It follows that if the imperial cult was a dominant part of that context, Luke would have related his message to those practices, even if only implicitly.

But, secondly, Luke quite explicitly evokes imperial motifs, and he does so right from the start of his narrative. In Luke 1-2 we find themes such as nature and society at peace through the birth of a divine child, with residual themes of judgement and cataclysm placed in the background, themes evoking the fulfilment of the saeculum aureum and raising pro- 
found questions of legitimation, political loyalties and so forth (cf also Brent 1999:73-139).

It is precisely against the backdrop of the concept of a saeculum aureum, inaugurated by Augustus' religious fulfilment of an imperfect republican cultus, and his extraordinary act of augury, that I would suggest the social background to Luke-Acts be understood: a narrative exploration of how some early Christians understood the relationship of their new faith to what their fellow citizens (and many among them themselves) believed was not only a political achievement in restoring civil order, but a religious achievement securing peace (by divine activity, so to speak).

\subsubsection{Gospel of Matthew}

A very helpful recent analysis is Carter (2001), who starts with the point of view that the usual synagogal context for the Gospel of Matthew is not necessarily wrong, but far too limiting. An appreciation of Roman imperial theology leads one to read Matthew quite differently from conventional approaches, in which Matthew is seen as resisting Rome with a social challenge and offering a vastly different vision and experience of human community.

\subsubsection{Thessalonians}

Paul's Letter to the Thessalonians contains a distinct eschatological emphasis. Given the Romanised character of first-century Thessaloniki, it is probably more historical to interpret this in the setting of the widespread Augustan apotheosis traditions and the provincial honouring of the Caesars (cf Judge 1971; Wengst 1987:19-21, 77-79; Hendrix 1991; Harrison 2002).

\subsection{The development of church order}

Allen Brent (1999) has drawn attention to the need to reassess the influence of the imperial cult on the development of ministerial order in the early church. His research makes clear that the Christian social construction of reality in the first centuries was fashioned in interaction with their pagan and imperial counterparts, the church order developing at an equal rate to and similarly with the priesthood of the imperial cult. By the time the church of Cyprian faced the the empire of Decius and Valerian as rival cultic organisations, both had behind them two centuries of interactive development. Brent shows how Cyprian places the Christian episcopatus, in which every local bishop stood for the whole community of the faithful, 
like the sun's rays emanating from a common source and giving unity and light to the natural order. At the centre of the nexus of intercommunion stood the bishop of Rome: the successors of Callistus are a converse reflection of the divine emperor as pontifex maximus, and mediating a unifying ontological reality just as (finally) the emperor Caracalla had claimed.

The episcopal order of the early church reflected the imperial order, not so much as a derivation or expression thereof (that as well) but almost as a sort of reverse image, a sort of opposing counter-culture. That is, at least some early Christian leaders did not encourage others to participate in the sacrament of imperial unity, but in the sacrament of the body of Christ - both sacraments pointing to the divinely constituted golden age.

Whether the early church successfully developed a contra-culture as Brent maintains, is quite problematic, but the issue surely needs to be pursued.

\subsection{The past is a different country}

The importance and implications of taking the imperial cult seriously as a profound aspect of the life-worlds of first-century followers of Jesus should be clear. Yet, the formidable gap separating us and them can far too easily be underestimated. It seems to me that even where New Testament scholars do consider the imperial cult seriously there is a tendency to discriminate, with an approach which acknowledges the Romans as different, but somehow the early Christians remain as more like us, more likeable and more acceptable.

The struggle of the followers of Jesus was not just against the imperial cult, but also with it, adapting and adopting, changing and incorporating. It is clear that the neglect of attempting to understand the imperial cult, and missing the religious elements thereof, also contributes to misunderstanding early Christianity. It is like, to adapt a metaphor of North (1986:252), writing about two love affairs. Describing the one (about emperor worship) is like writing a strictly biological account of the affair and then discovering with astonishment the absence of romantic elements in the story; but at the same time describing the other love affair (early Christianity) strictly in terms of love poems and terms of endearment and then noting with satisfaction the lack of material aspects in that liaison. 
The importance, value and power of the imperial cult in the first two centuries of the common era should be acknowledged, and consequently the early Christians's interaction with it carefully rethought. There may be much more at stake than simple contrasts.

\section{CONCLUDING REMARKS}

Claims of "self-evident" common sense needs to be re-examined from time to time. The imperial cult is often seen by New Testament scholars as empty, disguised politics, and its relevance to the New Testament considered as superficial at best.

Wright (2000:161) asks the question nicely, after emphasising that the worship of the emperor had become the dominant cult in the Roman world by the time of Paul:

“... were the emperor's subjects doing something religious, or something political? Surely both. But does not this answer make nonsense of the great divide between sacred and secular, religion and society that has run through not only scholarship but also whole societies?"

Cultural relativism demands contextual thinking; application of detailed historical work combined with self-criticism and responsibility. The implication of cultural relativism is not that nothing matters, but that the when, where, who and why matters a great deal. It is only then that we actually learn something, and then not just about the other but also about ourselves. Struggling with relativism is the road to self-understanding and insight into our own convictions.

Thus, a confrontation with something so strange such as the worship of an emperor, becomes an opportunity to consider the "advantages" of one's separative cosmology.

\section{Consulted literature}

Achtemeier, P J, Green, J B \& Meye Thompson, M 2001. Introducing the New Testament: its literature and theology. Grand Rapids: Eerdmans.

Alföldy, G 1996. Subject and ruler, subjects and methods: an attempt at a conclusion, in Small, A (ed), Subject and ruler: the cult of the ruling power in classical antiquity. Journal of Roman Archaeology Supplement 17, Ann Arbor: JRA, 254261.

Aune, D E 1993. Religions, Greco-Roman, in Hawthorne, G F \& Martin, R P (eds), Dictionary of Paul and his Letters, Downers Grove: InterVarsity Press, 786-796. 
Barrett, A A 1989. Caligula: the corruption of power. New Haven: Yale University Press.

Barton, T 1994. Astrology and the state in imperial Rome, in Thomas, N \& Humphrey, C (eds), Shamanism, history and the state, Ann Arbor: University of Michigan Press, 146-163.

-, 1995. Augustus and Capricorn: astrological polyvalency and imperial rhetoric. Journal of Roman Studies 85, 33-51.

Beard, M., North, J \& Price, S 1998. Religions of Rome, volume 1: a history. Cambridge: Cambridge University Press.

Bickerman, E 1973. Consecratio, in Den Boer, W (ed), Le culte des souverains dans l'empire Romain, Geneve: Vandoevres, 1-26.

Blaiklock, E M 1975. Emperor worship, in Tenney, M C (ed), The Zondervan pictorial encyclopedia of the Bible, vol 2: $D-G$, Grand Rapids: Zondervan, 301303.

Booth, W C 1979. Critical understanding: the powers and limits of pluralism. Chicago: University of Chicago Press.

Botha, P J J 1988. God, emperor worship and society: contemporary experiences and the Book of Revelation. Neotestamentica 22(2), 113-130.

Bowersock, G W 1973. Greek intellectuals and the imperial cult in the second century A.D, in Den Boer, W (ed), Le culte des souverains dans l'empire Romain, Geneve: Vandoevres, 179-206.

Brent, A 1999. The imperial cult and the development of church order: concepts and images of authority in paganism and early Christianity before the age of Cyprian. Leiden: Brill.

Carson, D A., Moo, D J \& Morris, L 1992. An introduction to the New Testament. Grand Rapids: Zondervan.

Carter, W 2001. Matthew: storyteller, interpreter, evangelist. Peabody: Hendrickson.

Cassidy, R J 2001. Christians and Roman rule in the New Testament: new perspectives. New York: Crossroad.

Charlesworth, M P 1935. Some observations on ruler-cult especially in Rome. HThR 28, 5-44.

Claridge, A 1998. Rome: an Oxford archaeological guide. Oxford: Oxford University Press.

Clauss, M 1996. Deus praesens. Der römische Kaiser als Gott. Klio 78(2), 400-433.

-, 2001. The Roman cult of Mithras: the god and his mysteries (Translated by $\mathrm{R}$ Gordon). New York: Routledge.

Court, J \& Court, K 1990. The New Testament world. Cambridge: University Press. 
Craffert, P F 1999. Mediating divine power: perspectives on religion in the biblical world. Pretoria: Biblia.

Cullmann, O 1963 [1957]. The christology of the New Testament (Translated by S C Guthrie \& C A M Hall). London: SCM Press. Original work published 1957.

Danker, F W 1982. Benefactor: epigraphic study of a Graeco-Roman and New Testament semantic field. St. Louis: Clayton.

De Villiers, J L 1998. Religious life, in Du Toit, A B (ed), Guide to the New Testament, vol 2: the New Testament milieu, Halfway House: Orion, 191-214.

DeMaris, R 2002. Cults and the imperial cult in early Roman Corinth: literary versus material record, in Labahn, M \& Zangenberg, J (Hrsg), Zwischen den Reichen: Neues Testament und Römische Herrschaft, Tübingen: A Francke Verlag, 73-94.

Ehrenberg, V \& Jones, A H M (Comps.). 1955. Documents illustrating the reigns of Augustus and Tiberius, 2nd ed. Oxford: Clarendon Press.

Fears, J R 1981a. The cult of Jupiter and Roman imperial ideology. Aufstieg und Niedergang der römischen Welt 2.17.1, 3-141.

-, 1981b. The cult of virtues and Roman imperial ideology. Aufstieg und Niedergang der römischen Welt 2.17.2, 827-948.

-, 1981c. The theology of Victory at Rome: approaches and problems. Aufstieg und Niedergang der römischen Welt 2.17.2, 736-826.

Feeney, D 1988. Literature and religion at Rome: cultures, contexts, and beliefs. Cambridge: Cambridge University Press.

Filson, F V 1964. A New Testament history. London: SCM Press.

Fishwick, D 1978. The development of provincial ruler worship in the western Roman empire. $A N R W 2.16 .2,1201-1253$.

-, 1987a. The imperial cult in the Latin West: studies in the ruler cult of the western provinces of the Roman empire, volume 1.1. Leiden: Brill.

-, 1987b. The imperial cult in the Latin West: studies in the ruler cult of the western provinces of the Roman empire, volume 1.2. Leiden: Brill.

-, 1991. The imperial cult in the Latin West: studies in the ruler cult of the western provinces of the Roman empire, volume 2.1. Leiden: Brill.

-, 1992. The statue of Julius Caesar in the Pantheon. Latomus 51, 329-336.

-, 1996. Four temples at Tarraco, in Small, A (ed), Subject and ruler: the cult of the ruling power in classical antiquity. Journal of Roman Archaeology Supplement 17, 165-185. Ann Arbor: JRA.

Frenschkowski, M 2002. Kyrios in context: Q 6:46, the emperor as "lord" and the political implications of Christology in Q, in Labahn, M \& Zangenberg, J (Hrsg.), 
Zwischen den Reichen: Neues Testament und römische Herrschaft. Tübingen: Francke Verlag, 95-118.

Freyne, S 1980. The world of the New Testament. Dublin: Veritas.

Futrell, A 1997. Blood in the arena: the spectacle of Roman power. Austin: University of Texas Press.

Garnsey, P \& Saller, R 1987. The Roman empire: economy, society and culture. Berkeley: University of California Press.

Gordon, R L 1979. The real and the imaginary: production and religion in the GraecoRoman world. Art History 2(1), 5-34.

Gordon, R 1990. From republic to principate: priesthood, religion and ideology, in Beard, M \& North, J (eds), Pagan priests: religion and power in the ancient world, London: Duckworth, 179-198.

Gradel, I 2002. Emperor worship and Roman religion. Oxford: Clarendon Press.

Grant, R M 1962. Emperor-worship. The Interpreter's Dictionary of the Bible 2, 98 100.

Hanfmann, G M A 1983. Sardis from prehistoric Roman times: results of the archaeological exploration of Sardis 1958-1975. Cambridge (M): Harvard University Press.

Harland, P A 1996. Honours and worship: emperors, imperial cults and asssociations at Ephesus (first to third centuries C.E.). Studies in Religion 25(3), 319-334.

Harrison, J R 2002. Paul and the imperial cult at Thessaloniki. Journal for the study of the New Testament 25(1), 71-96.

Hänlein-Schäfer, H 1985. Veneratio Augusti: eine Studie zu den Tempeln des ersten römischen Kaisers. Rome.

Hendrix, H L 1991. Archaeology and eschatology at Thessalonica, in Pearson, B A (ed), The future of early Christianity, Minneapolis: Fortress Press, 107-118.

Herz, P 1988. Der römische Kaiser und der Kaiserkult: Gott oder primus inter pares, in Zeller, D (Hrsg), Menschwerdung Gottes - Vergöttlichung von Menschen, Göttingen: Vandenhoeck, 136-167.

Hopkins, K 1978. Divine emperors or the symbolic unity of the Roman empire, in Conquerors and slaves: sociological studies in Roman history 1, Cambridge: Cambridge University Press, 197-242.

Horsley, R A 2000. Rhetoric and empire - and 1 Corinthians, in Horsley, R A (ed), Paul and politics: ekklesia, Israel, imperium, interpretation. Essays in honor of Krister Stendahl, Harrisburg: Trinity Press International, 72-102. 
-, 1997. The gospel of imperial salvation: introduction, in Horsley, R A (ed), Paul and empire: religion and power in Roman imperial society, Harrisburg: Trinity Press International, 10-24.

Hoskins-Walbank, M E 1996. Evidence for the imperial cult in Julio-Claudian Corinth, in Small, A (ed), Subject and ruler: the cult of the ruling power in classical antiquity. Journal of Roman Archaeology Supplement 17, Ann Arbor: JRA, 201-212.

Judge, E A 1971. The decrees of Caesar at Thessalonica. Reformed Theological Review 30(1), 1-7.

Koester, H 1966. Paul and Hellenism, in Hyatt, J P (ed), The Bible in modern scholarship, London: Carey Kingsgate Press, 187-195.

Liebeschuetz, J H W G 1979. Continuity and change in Roman religion. Oxford: Clarendon.

Lietaert Peerbolte, B J 2002. To worship the beast: the Revelation of John and the imperial cult in Asia Minor, in Labahn, M \& Zangenberg, J (Hrsg), Zwischen den Reichen: Neues Testament und Römische Herrschaft, Tübingen: A Francke Verlag, 239-262.

Lintott, A W 1993. Imperium Romanum: politics and administration. London: Routledge.

Lohse, E 1976. The New Testament environment. London: SCM Press.

MacMullen, R, 1969. Constantine. London: Weidenfeld and Nicolson.

-, 1980. Roman elite motivation: three questions. Past and Present 88, 3-16.

Martin, R P 1978. New Testament foundations: a guide for New Testament students, volume 2. The Acts, the Letters, the Apocalypse. Grand Rapids: Eerdmans.

Meier, C 1990. C Caesar divi filius and the formation of the alternative in Rome, in Raaflaub, K A \& Toher, M (eds), Between Republic and Empire: interpretations of Augustus and his principate, Berkeley: University of California Press, 54-70.

Mellor, R 1975. Q EA RWM H: the worship of the goddess Roma in the Greek world. Göttingen: Vandenhoeck.

Mellor, R 1992. The local character of Roman imperial religion. Athenaeum 70, 380400.

Millar, F 1973. The imperial cult and the persecutions, in Den Boer, W (ed), Le culte des souverains dans l'empire Romain, Geneve: Vandoevres, 145-65.

-, 1977. The emperor in Roman the Roman world. London: Duckworth.

Nock, A D 1934. Religious developments from the close of the Republic to the reign of Nero. Cambridge ancient history 10, 465-511. 
North, J A 1986. Religion and politics, from Republic to principate. Journal of Roman Studies 76, 251-259.

-, 1990. Diviners and divination at Rome, in Beard, M \& North, J (eds), Pagan priests: religion and power in the ancient world, London: Duckworth, 51-71.

Oudemans, T C W \& Lardinois, A P M H 1987. Tragic ambiguity: anthropology, philosophy and Sophocles' Antigone. Leiden: Brill.

Phillips, C R 1986. The sociology of religious knowledge in the Roman empire to A.D 284. ANRW 2.16.3, 2677-2773.

Pleket, H W 1965. An aspect of the emperor cult: imperial mysteries. HThR 58, 331347.

Pollini, J 1990. Man or god: divine assimilation and imitation in the late Republic and early principate, in Raaflaub, K A \& Toher, M (eds), Between Republic and Empire: interpretations of Augustus and his principate, Berkeley: University of California Press, 334-357.

Pötscher, W 1978. "Numen" und "numen Augusti". Aufstieg und Niedergang der römischen Welt 2.16.1, 355-392.

Pregeant, R 1995. Engaging the New Testament: an interdisciplinary introduction. Minneapolis: Fortress.

Price, S R F 1980. Between man and God: Sacrifice in the Roman imperial cult. Journal of Roman Studies 70, 28-43.

-, 1984a. Gods and emperors: the Greek language of the Roman imperial cult. Journal of Hellenic Studies 104, 79-95.

-, 1984b. Rituals and power: the Roman imperial cult in Asia Minor. Cambridge: University Press.

Reasoner, M 1997. Emperor, emperor cult, in R P Martin \& P H Davids (eds), Dictionary of the later New Testament and its developments, Downers Grove: InterVarsity Press, 321-326.

Reicke, B 1968. The New Testament era: the world of the Bible from 500 B.C to A.D 100. Philadelphia: Fortress Press.

Reynolds, J 1996. Ruler cult at Aphrodisias in the late Republic and under the JulioClaudian emperors, in Small, A (ed), Subject and ruler: the cult of the ruling power in classical antiquity. Journal of Roman Archaeology Supplement 17, 4150. Ann Arbor: JRA.

Rose, H J 1970. Vediovis, Veiovis, Vedius. Oxford Classical Dictionary (2nd. ed.), 1110.

Selvidge, M J 1999. The New Testament: a timeless Book for all peoples. Upper Saddle River, NJ: Prentice Hall. 
Shotter, D 1991. Augustus Ceasar. London: Routledge.

Simon, E 1986. Augustus: Kunst und Leben in Rom um die Zeitenwende. München: Hirmer Verlag.

Syme, R 1939. Roman revolution. Oxford: Clarendon.

Toynbee, J M C 1947. Ruler apotheosis in ancient Rome. NC 7, 120-140.

Tripolitis, A 2002. Religions of the Hellenistic-Roman age. Grand Rapids: Eerdmans.

Turcan, R 2000. The gods of ancient Rome: religion in everyday life from archaic to imperial times. New York: Routledge.

Van Rossum, J A 1994. Astrologie en politiek in de Romeinse keizertijd. Lampas 27(4), 343-358.

Versnel, H S 1970. Triumphus: an inquiry into the origin, development and meaning of the Roman triumph. Leiden: Brill.

Versnel, H S 1988. Geef de keizer wat des keizers is en Gode wat Gods is: een essay over een utopisch conflikt. Lampas 21(3), 233-256.

Walbank, F W 1967. The Scipionic legend. Proceedings of the Cambridge Philological Society 13(193), 54-69.

Wallace-Hadrill, A 1993. Augustan Rome. London: Bristol Classical Press.

Wardle, D 2002. Deus or divus: the genesis of Roman terminology for deified emperors and a philosopher's contribution, in Clark, G \& Rajak, T (eds), Philosophy and power in the Graeco-Roman world, Oxford: Oxford University Press, 181-192.

Wardman, A 1982. Religion and statecraft among the Romans. Baltimore: John Hopkins University Press.

Weinstock, S 1971. Divus Julius. Oxford: Clarendon.

Wengst, K 1987. Pax Romana and the peace of Jesus Christ. London: SCM Press.

Wright, N T 2000. Paul's gospel and Caesar's empire, in Horsley, R A (ed), Paul and politics: ekklesia, Israel, imperium, interpretation, Harrisburg: Trinity Press International, 160-183.

Zanker, P 1990. Augustus und die Macht der Bilder. München: Verlag C.H Beck. 